International Journal of Agriculture, Environment and Bioresearch

Vol. 4, No. 03; 2019

ISSN: $2456-8643$

\title{
CARCASS TRAITS AND MEAT QUALITY OF RABBITS FED REGIMENS CONTAINING CAROB PODS AND REARED UNDER TUNISIAN SUMMER CONDITIONS
}

\author{
Hadj Ayed Madiha ${ }^{1}$, Aïssa Asma ${ }^{1}$ and Chakroun Imen ${ }^{1}$ \\ ${ }^{1}$ Departement of Animal Production, Higher Institute of Agricultural Sciences of Chott Mariem, IRESA and \\ University of Sousse, Sousse, Tunisia \\ http://doi.org/10.35410/IJAEB.2019.318330
}

\begin{abstract}
This study aims to evaluate the effects of feed incorporation of Tunisian local carob pods, on meat quality. A growth performance assay was carried out in summer (July-August), on a total of one hundred twenty weaned four weeks of age New Zealand rabbits and weighing $607 \pm 13 \mathrm{~g}$. Animals were housed in 60 cages ( 2 rabbits/cage). Two iso-proteic and iso-energetic diets ("Control": without carob and "Carob": $20 \%$ carob) were formulated and each diet was allotted to a group of sixty rabbits (thirty cages $\mathrm{x}$ two rabbits). Growth performance was registered and fifteen male rabbits per diet of 11 weeks of age; were slaughtered and processed, to analyze the effects of diets on carcass traits. Growth performance data did not reveal any difference between group ( $>0.05)$ and viability was significantly improved with carob $(p<0.01)$, besides the high registered temperatures. Carcass traits showed similar carcass yields and higher proportions of the liver and the empty stomach and colon. In addition carob improved protein content and reduced fat in BF meat. In conclusion, carob pods can be incorporated in growing rabbit's diets at $20 \%$ without any negative incidence on carcass traits. It may also improve the viability of rabbits reared in hot climate.
\end{abstract}

Keywords: rabbits, carob, carcass quality, meat quality.

\section{INTRODUCTION}

Rabbit meat production in Tunisia, is around $2300 \mathrm{~T}$ (OEP, 2018). This production, compared to countries such as Algeria, Italy and France, is relatively low. Indeed, rabbit meat consumption is marginal $(0.250 \mathrm{~kg} / \mathrm{capita} /$ year) (GIPAC, 2018). Nonetheless, there's a growing interest among Tunisian trend consumers, in healthy food and in the near future the interest to rabbit meat will increase among Tunisian society (GIPAC, 2018). Notwithstanding, the high cost of imported raw materials such as soybean meal, grains or alfalfa meal; is one of the most important challenges that rabbit production sector is facing in Tunisia. Hence, in this context, local feed resources valorization could be an alternative to substitute imported raw materials in rabbit feeds. In view this background, we were interested in carob pods. Carob tree (Ceratonia siliqua L.) is an agro-sylvo-pastoral dioecious tree of the fabaceae family, which is well adapted to climatic risks and long drought periods. Thanks to its adaptation properties to water constraints, this tree 
is easily installed in arid and semi-arid zones. In Tunisia, carob trees occupy wet, sub-humid, and semi-arid upper floors, with a hot to temperate variant. It is mainly found along the Tunisian coast. FAOSTAT (2018) reported $850 \mathrm{~T}$ of pod production in Tunisia in 2016. Carob is widely used in Mediterranean region for nutritional, medicinal, ornamental, environmental and industrial purposes. Kotrotsios et al. (2012) reported that carob pods were also used in animal feeds. They are rich sources of sugars and gross energy but their high content of tannins, constrains its use in this field.

In the present study, we aim to evaluate essentially the effects of carob pods incorporation at $20 \%$ in feeds on carcass and meat quality of growing rabbits reared under Tunisian summer conditions.

\section{MATERIALS AND METHODS}

\subsection{Environmental conditions during the assay}

This study was conducted in the experimental farm of the higher institute of agricultural science of Chott Mariem, during a period of 49 days extended between $11^{\text {th }}$ of August to $22^{\text {nd }}$ of September. The area is located in the eastern central coast of Tunisia in the latitude of $35^{\circ} 56^{\prime} 17^{\prime}$ ', $\mathrm{N}$ and the longitude $10^{\circ} 33^{\prime} 18^{\prime \prime} \mathrm{E}$. Animals were housed in a static ventilation hutch where inside temperature and humidity were recorded daily (figure 1).

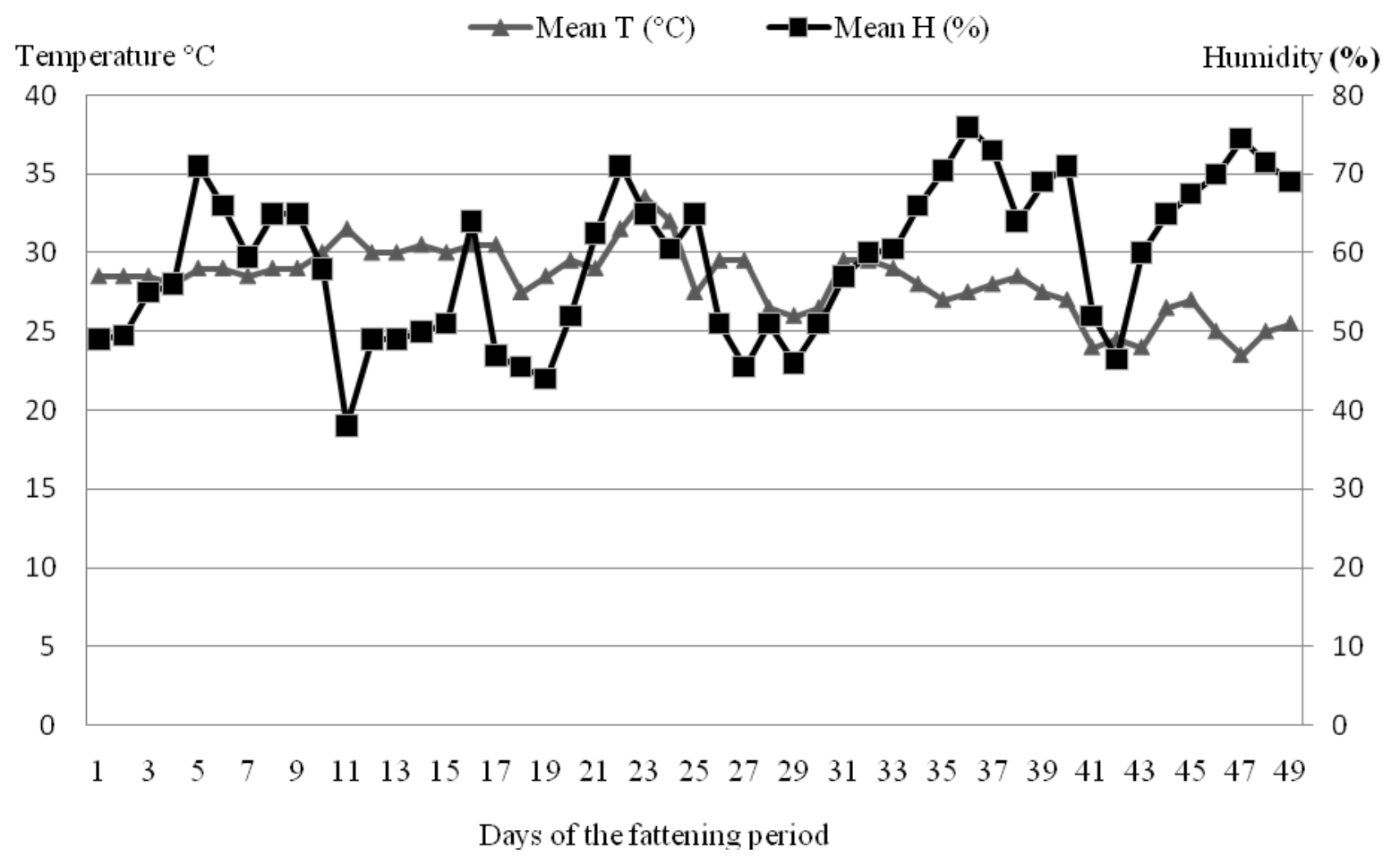

Figure 1: Humidity $(\%)$ and temperature ${ }^{\circ}(\mathrm{C})$ variation 
Vol. 4, No. 03; 2019

ISSN: 2456-8643

\subsection{Animals}

One hundred twenty weaned 28 days of age male and female New Zealand rabbits, with an average initial body weight $607 \pm 13 \mathrm{~g}$, were randomly divided into two homogeneous groups and housed in flat-deck wired cages of $76 \mathrm{~cm}$ of length, $45 \mathrm{~cm}$ of width and $25 \mathrm{~cm}$ of height and each cage is made up of two rabbits (male and female). All procedures were achieved under Law No. 2005-95 of the Tunisian Agriculture and Water Resources Minister for livestock and animal products.

\subsection{Diets}

Rabbits fed ad libitum isoenergetic and isoproteic diets: control diet and carob diet in which $20 \%$ carob was introduced until the end of the trial (11 weeks of age). Raw material components and chemical composition of the experimental diets are reported in Table 1.

Table 1: Feeds composition and nutritive value of Control and Carob diets and Carob $\operatorname{pods}(\%)$

\begin{tabular}{|c|c|c|c|}
\hline & Control diet & Carob diet & Carob pods \\
\hline Barley & 40.6 & 23 & - \\
\hline DDGS Maize & 10 & 11 & - \\
\hline Soybean meal & 16 & 19 & - \\
\hline Alfalfa hay & 32 & 25.6 & - \\
\hline Carob pods & 0 & 20 & 100 \\
\hline Calcium carbonate & 0.2 & 0.2 & - \\
\hline Monocalcic phosphate & 0.2 & 0.2 & - \\
\hline Sodium Chloride & 0.5 & 0.5 & - \\
\hline DL-Methionine & 0.05 & 0.05 & - \\
\hline L-Lysine & 0.02 & 0.02 & - \\
\hline Premix* & 0.5 & 0.5 & - \\
\hline $\mathrm{DM}(\%)$ & 92.9 & 92.5 & 86.5 \\
\hline OM (\% DM) & 91.7 & 92.1 & 96.9 \\
\hline $\mathrm{CP}(\% \mathrm{DM})$ & 19.89 & 20.25 & 5.31 \\
\hline $\mathrm{EE}(\% \mathrm{DM})$ & 2.86 & 2,64 & 0.42 \\
\hline $\mathrm{CF}(\% \mathrm{DM})$ & 15.13 & 14.63 & 8.96 \\
\hline
\end{tabular}


International Journal of Agriculture, Environment and Bioresearch

Vol. 4, No. 03; 2019

ISSN: $2456-8643$

\begin{tabular}{|llll}
$\mathrm{NDF}(\% \mathrm{DM})$ & 35.43 & 34.93 & 28.26 \\
$\mathrm{ADF}(\% \mathrm{DM})$ & 16.6 & 19.7 & 27.00 \\
$\mathrm{ADL}(\% \mathrm{DM})$ & 3.2 & 7.3 & 18.70 \\
Condensed Tannins & - & - & 1.90 \\
$\mathrm{DE}(\mathrm{kcal} / \mathrm{kg})$ & 2422 & 2417 & 1850
\end{tabular}

DM: Dry matter; OM: Organic matter; CP: Crude protein; CF: Crude fiber; NDF: Neutral detergent fiber; ADF: Acid detergent fiber; ADL: Acid detergent lignin; DE: Digestible energy *Premix Composition contains (g/kg premix): $\mathrm{Zn}, 7$; $\mathrm{Mg}, 5 ; \mathrm{Mn}, 5 ; \mathrm{Cu}, 2.3 ; \mathrm{Fe}, 3.4 ; \mathrm{I}, 0.12 ; \mathrm{Se}$, 0.025 ; Co, 0.03; thiamine, 0.05 ; riboflavin, 0.04 ; folic acid 0.4; vitamin K3, 0.2; biotine, 0.0015 ; vitamin A, 850000IU, Vitamin D3,175000 IU; Vitamin E 1500 IU

\subsection{Carcass traits}

After 49 days of fattening period a total number of thirty rabbits (fifteen male rabbits per diet), with an average live weight (1957 $\pm 75 \mathrm{~g}$ ) were slaughtered after 12 hours feed withdrawal. Rabbit slaughtering followed national regulations and carcasses were prepared as described by Blasco and Ouhayoun (1996). Hot carcass, skin, digestive tract were weighted and expressed as percentage of slaughter weight. Digestive tract was dissected and washed to determine the different proportions of full and empty stomach, small intestinal, caecum and colon. After $24 \mathrm{~h}$ chilling at $+4{ }^{\circ} \mathrm{C}$, commercial carcass, head, liver and kidneys were weighed, and lungs, esophagus, trachea, thymus and heart were recorded as a single weight ( $\Sigma$ Organs). Dressing percentage was also calculated and commercial carcass weight was recorded. Commercial carcass yield was calculated consequently. Carcasses were graded according to AFNOR (2004) to evaluate the adiposity (from 1, scarce, to 5, excessive). Furthermore, carcasses were cut as described by Blasco and Ouhayoun (1996). The fore part, intermediate part, hind part, scapular fat and perirenal fat were weighed and then converted to percentages of reference carcass. The ratio meat to bone was calculated after dissection of one of the legs.

\subsection{Meat quality analysis}

Biceps femoris (BF) and Longissimus dorsi (LD) $\mathrm{pH}$, was measured at the level of the 5th lumbar vertebra using a $\mathrm{pH}$-meter (type $330 \mathrm{i} / \mathrm{SET} \mathrm{WTW}$ ) after slaughtering (initial $\mathrm{pH}_{20 \mathrm{mn}}: \mathrm{pHi}$ ) and at $24 \mathrm{~h}$ post-mortem (ultimate $\mathrm{pH}: \mathrm{pHu}$ ).

Water holding capacity was estimated by measuring total water loss, which is the sum of drip and cooking loss, according to Honikel (1998) method and expressed as percentage of weight loss. Meat samples of BF and LD were weighted and placed in polyethylene bags and suspended in a refrigerator at $+4^{\circ} \mathrm{C}$, from the second to the seventh day of the storage period. They were weighed daily to evaluate the drip loss. Subsequently, they were cooked in water bath heated at $75^{\circ} \mathrm{C}$ for one hour and meat internal temperature was $70^{\circ} \mathrm{C}$. 


\section{International Journal of Agriculture, Environment and Bioresearch}

Vol. 4, No. 03; 2019

ISSN: $2456-8643$

Chemical composition (Dry matter, ash, crude protein, and crude fat) of meat leg and saddle was carried out according the AOAC (1995).

2.6. Color measurements: Meat color was measured on Biceps femoris (BF) and Longissimus dorsi (LD) (at the sixth lumbar vertebra (from the second to the seventh) and lightness (L*), redness $\left(\mathrm{a}^{*}\right)$, yellowness $\left(\mathrm{b}^{*}\right)$ were recorded, using a Minolta CR-401 chromameter according to CIE L*a*b* system (Hernandez and Dalle Zotte, 2010).

\subsection{Sensory evaluation}

A taste panel assay was carried out to evaluate meat sensory characteristics. The right leg from each of 4 carcass rabbits per diet was cut into 6 uniform pieces of boneless meat. Meat samples were cooked in an electric oven preheated to $240^{\circ} \mathrm{C}$ for about $40 \mathrm{~min}$ to an internal temperature of $80^{\circ} \mathrm{C}$. They were distributed in previously coded plates. Eight trained panelists participated to the sensory evaluation. Each panelist was installed in a single cabin and received successively three plates with two hot pieces of meat in each plate. Panelists were led to observe, smell, taste and classify the pieces on different scales of increasing intensity of color, tenderness, juiciness and flavor. Water and bread were presented to each panelist so that they could change the taste of his mouth after tasting each sample.

\subsection{Chemical analysis}

Dry matter (DM), organic matter $(\mathrm{OM})$, crude protein $(\mathrm{CP})$ and extract ether (EE) were measured according AOAC (1995) procedures. Crude fiber (CF) and neutral detergent fiber (NDF), acid detergent fiber (ADF) and acid detergent lignin (ADL) contents were analyzed according Weende and Van Soest et al. (1991) methods, respectively, while CP was analyzed according to Kjeldahl nitrogen method. Condensed tannins in carob pods were analyzed by using the vanilline method reported by MAKKAR and BECKER (1993).

\subsection{Statistical analysis}

All the data were subjected to a variance analysis using the following general linear model $(\mathrm{GLM}): Y_{i j}=\mu+$ Diet $_{i}+\varepsilon_{i j}$

Where, $Y_{i j}$ is the observation of the dependent variable, $\mu$ is the overall mean, Diet ${ }_{i}$ is the effect of diets ( $i=$ Control and Carob) and $\varepsilon_{i j}$ is the residual error.

The software SAS (SAS institute, 2003) was used to evaluate the diet's effect. The effect of carob inclusion was evaluated by least square difference (LSD) test. The level of statistical significance was set at $\mathrm{p}<0.05$.

\section{RESULTS}

\subsection{Growth performance}

Overall data indicated in Table 2 showed that, carob fruit did not reduce growth performance (p>0.05). Indeed, final LBW and ADG were $2012 \mathrm{~g}$ and $28.6 \mathrm{~g} / \mathrm{d}$ and $1955 \mathrm{~g}$ and $27.5 \mathrm{~g} / \mathrm{d}$, in control and carob lots, respectively. Feed intake and FCR were similar in both groups and mortality rate was significantly reduced $(\mathrm{p}<0.05)$ in carob rabbits, $(14.29 \%$ vs. $2.04 \%)$. Main mortalities were observed when temperature exceeded $30^{\circ} \mathrm{C}$.

\section{Table 2: Effect of diets on growth performance}


Vol. 4, No. 03; 2019

ISSN: 2456-8643

\begin{tabular}{|lllll|}
\hline & Control & Carob & SEM & Significance \\
\hline Initial LBW (g) & 609 & 606 & 2.459 & $\mathrm{~ns}$ \\
Final LBW (g) & $2012^{\mathrm{a}}$ & $1955^{\mathrm{b}}$ & 12.16 & $*$ \\
ADG (g/day) & 28.6 & 27.5 & 1.456 & $\mathrm{~ns}$ \\
FI (g/day) & 111 & 112 & 1.550 & $\mathrm{~ns}$ \\
FCR (g of FI/g ADG) & 3.88 & 4.08 & 0.341 & $\mathrm{~ns}$ \\
MR (\%) & $14.29^{\mathrm{a}}$ & $2.04^{\mathrm{b}}$ & 1.394 & $* *$ \\
\hline
\end{tabular}

a,b: Least square means in the same row with different superscript letters are significantly different; SEM: Pooled standard error of the mean, ns non significant.

$* \mathrm{P}<0.05 ; * * \mathrm{P}<0.001 ;$

\subsection{Carcass traits}

Live body weight of the slaughtered rabbits, was similar (Table 3) and hot and cold carcass weights were higher in control group. Hot and commercial and reference carcass yields were comparable in both groups, likewise skin and the gastrointestinal tract proportions. Carob feed decreased the liver weight about $(-0.26 \%)$ and no difference was detected in the full digestive organs weights $(p>0.05)$. However, emptied of their contents, the stomach and colon were heavier in carob group $(\mathrm{p}<0.05)$, (Table 3$)$.

Table 3: Effect of carob on rabbit slaughter performances, offals and digestive tract

\begin{tabular}{|lllll|}
\hline & Control & Carob & SEM & Significance \\
\hline Live body weight (g) & 1981 & 1933 & 19.43 & $\mathrm{~ns}$ \\
Hot carcass weight $(\mathrm{g})$ & $1254^{\text {a }}$ & $1221^{\mathbf{b}}$ & 10.07 & $*$ \\
Commercial carcass weight (g) & $1239^{\text {a }}$ & $1204^{\mathbf{b}}$ & 9.29 & $*$ \\
Hot carcass yield (\%) & 63.33 & 63.18 & 0.441 & $\mathrm{~ns}$ \\
Commercial carcass yield (\%) & 62.58 & 62.29 & 0.468 & $\mathrm{~ns}$ \\
Reference carcass yield (\%) & 52.41 & 52.14 & 0.457 & $\mathrm{~ns}$ \\
Skin (\% body weight) & 14.43 & 15.23 & 0.324 & $\mathrm{~ns}$ \\
Digestive tract (\% body weight) & 14.49 & 13.90 & 0.426 & $\mathrm{~ns}$ \\
Head (\% commercial carcass weight) & 9.80 & 10.03 & 0.245 & $\mathrm{~ns}$ \\
Liver (\%commercial carcass weight) & $3.45^{\text {a }}$ & 3.19 b & 0.084 & $*$ \\
\end{tabular}


Kidney (\%commercial carcass weight)

$\Sigma$ Offals $^{+}(\%$ commercial carcass weight $)$

Stomach and intestines' proportions

(\% Digestive tract)

Full

Stomach

Small intestine

Caecum

Colon

Empty

Stomach

Small intestine

Caecum

Colon
23.02

18.50

36.39

11.81

$6.10^{\mathrm{b}}$

$6.81^{\mathrm{a}}$

$0.185 *$

0.95

8.85

$6.22^{\mathrm{b}}$

20.76

18.91

39.22

15.97

1.00

9.59

$8.49^{a}$
0.88

1.95

0.034 ns

$0.357 \mathrm{~ns}$

$0.443 \quad * *$

a,b Least square means in the same row with different superscript letters are significantly different; SEM: Pooled standard error of the mean; ns non significant.

$* \mathrm{P}<0.05 ; * * \mathrm{P}<0.001$;

+thymus + trachea +esophagus + lungs + heart

Fore, hind and intermediate parts, revealed a similarity between both treatments (Table 4). Nevertheless, adiposity analysis showed comparable proportions of scapular and peri-renal fat $(0.46 \%$ and $1.2 \%$, respectively) between both lots. Same findings were obtained by the visual assessment, thus, the score assigned to the carcass of rabbits fed the control diet was identical to that detected in those of rabbits receiving carob regimen (2.71 and 2.79, respectively). In addition, rabbits from both treatments showed no difference in meat to bone ratios ( 7.58 and 7.47, respectively).

Table 4: Effect of carob on fore, intermediate and hind parts proportions, body composition and fatness ( $\%$ commercial carcass yield)

\begin{tabular}{|lllll|}
\hline & Control & Carob & SEM & Significance \\
\hline Fore part & 35.3 & 35.8 & 0.339 & $\mathrm{~ns}$
\end{tabular}




\begin{tabular}{|lllll} 
Intermediate part & 26.8 & 26.5 & 0.562 & ns \\
Hind part & 37.9 & 37.6 & 0.623 & ns \\
Meat to bone ratio of the hind leg & 7.58 & 7.47 & 0.252 & ns \\
Scapular fat & 0.46 & 0.46 & 0.035 & ns \\
Perirenal fat & 1.18 & 1.28 & 0.105 & ns \\
Adiposity $^{++}$ & 2.71 & 2.79 & 0.204 & ns
\end{tabular}

a,b: Least square means in the same row with different superscript letters are significantly different $(\mathrm{P}<0.05)$; $^{++}$: Adiposity Visual appreciation; SEM: Pooled standard error of the mean, ns non significant.

$* * \mathrm{P}<0.001$

The initial $\mathrm{pH}$ values (Table 5) measured on the Biceps femoris (BF) and Longissimus dorsi (LD) muscles were comparable between rabbits in both groups. Ultimate $\mathrm{pH}\left(\mathrm{pH}_{\mathrm{u}}\right)$ was lower than the initial $\mathrm{pH}\left(\mathrm{pH}_{\mathrm{i}}\right)$ of 1.5 and 1.4 points in $\mathrm{BF}$ and $\mathrm{LD}$ muscle, respectively.

The regimen did not influence meat drip, cooking and total water losses (Table 5). Indeed, these parameters, measured on the BF and LD, were similar and showed no difference between both diets, thus avoiding the presence of any bounded effect to the carob use ( $p>0.05)$. Moreover, lightness $\left(\mathrm{L}^{*}\right)$, redness $\left(\mathrm{a}^{*}\right)$ and yellowness $\left(\mathrm{b}^{*}\right)$ results shown in Table 5, were not affected by carob feed inclusion.

Table 5: Effect of carob on $\mathrm{pH}$ and water losses

\begin{tabular}{|lllll|}
\hline & Control & Carob & SEM & Significance \\
\hline Biceps femoris (BF) & & & & \\
$\mathrm{pH}_{\mathrm{i}}$ & 6.79 & 6.90 & 0.074 & $\mathrm{~ns}$ \\
$\mathrm{pH}_{\mathrm{u}}$ & 5.67 & 5.73 & 0.056 & $\mathrm{~ns}$ \\
Total water loss & 20.54 & 17.78 & 1.503 & $\mathrm{~ns}$ \\
Drip loss & 3.81 & 3.70 & 0.176 & $\mathrm{~ns}$ \\
Cooking loss & 16.74 & 14.09 & 1.529 & $\mathrm{~ns}$ \\
$\mathrm{~L}^{*}$ & 60.64 & 61.37 & 0.447 & $\mathrm{~ns}$ \\
$\mathrm{a}^{*}$ & 9.89 & 9.45 & 0.348 & $\mathrm{~ns}$ \\
$\mathrm{~b}^{*}$ & 3.87 & 4.26 & 0.188 & $\mathrm{~ns}$ \\
Longissimus dorsi $(\mathrm{LD})$ & & & & \\
\hline
\end{tabular}


Vol. 4, No. 03; 2019

ISSN: $2456-8643$

\begin{tabular}{|lllll|}
\hline $\mathrm{pH}_{\mathrm{i}}$ & 6.98 & 6.94 & 0.071 & $\mathrm{~ns}$ \\
$\mathrm{pH}_{\mathrm{u}}$ & 5.53 & 5.58 & 0.048 & $\mathrm{~ns}$ \\
Total water loss & 26.31 & 22.24 & 1.696 & $\mathrm{~ns}$ \\
Drip loss & 6.09 & 5.36 & 0.327 & $\mathrm{~ns}$ \\
Cooking loss & 20.21 & 16.88 & 1.630 & $\mathrm{~ns}$ \\
$\mathrm{~L}^{*}$ & 70.06 & 70.32 & 0.674 & $\mathrm{~ns}$ \\
$\mathrm{a}^{*}$ & 8.39 & 8.07 & 0.639 & $\mathrm{~ns}$ \\
$\mathrm{~b}^{*}$ & 5.81 & 6.34 & 0.217 & $\mathrm{~ns}$ \\
\hline
\end{tabular}

(L*) Lightness, $\left(\mathrm{a}^{*}\right)$ redness, $\left(\mathrm{b}^{*}\right)$ yellowness, SEM: Pooled standard error of the mean, ns non significant

Table 6 summarized the results of the meat chemical analyzes. Although the dietary protein intake was similar for both diets, these results showed higher $\mathrm{CP}$ and lower crude fat contents in carob rabbit's BF (20.82 vs 21.47 and 7.61 vs 7.23 ), respectively while LD meat chemical

Table 6: Diets effects on meat chemical composition (\%)

\begin{tabular}{|c|c|c|c|c|}
\hline & Control & Carob & SEM & Significance \\
\hline \multicolumn{5}{|l|}{$\overline{\mathrm{BF}}$} \\
\hline Moisture & 76.13 & 76.03 & 0.213 & ns \\
\hline $\mathrm{CP}$ & $20.82^{b}$ & $21.47^{\mathrm{a}}$ & 0.195 & $* *$ \\
\hline Crude fat & $7.61^{\mathrm{a}}$ & $7.23^{\mathrm{b}}$ & 0.12 & * \\
\hline \multicolumn{5}{|l|}{ LD } \\
\hline Moisture & 75.56 & 76.08 & 0.196 & $\mathrm{~ns}$ \\
\hline $\mathrm{CP}$ & 20.82 & 21.47 & 0.508 & ns \\
\hline Crude fat & 1.72 & 1.69 & 0.15 & $\mathrm{~ns}$ \\
\hline
\end{tabular}

a,b: Least square means in the same row with different superscript letters are significantly different $(\mathrm{P}<0.05)$; SEM: Pooled standard error of the mean, ns non significant.

$* \mathrm{P}<0.05, * * \mathrm{P}<0.001$

Sensory evaluation didn't show any differences attributed to diets (Table 7) and rabbit meat in control and carob lots was tender, more or less juicy, with a fairly strong odor and intense flavor and light color. 
International Journal of Agriculture, Environment and Bioresearch

Vol. 4, No. 03; 2019

ISSN: $2456-8643$

Table 7: Diets effects on sensorial characteristic of leg meat

\begin{tabular}{|lllll|}
\hline & Control & Carob & SEM & Significance \\
\hline Tenderness & 7.15 & 6.36 & 0.366 & $\mathrm{~ns}$ \\
Juiciness & 6.15 & 5.50 & 0.331 & $\mathrm{~ns}$ \\
Color & 4.85 & 4.34 & 0.382 & $\mathrm{~ns}$ \\
Odor & 5.98 & 6.07 & 0.307 & $\mathrm{~ns}$ \\
Flavor & 5.19 & 4.95 & 0.418 & $\mathrm{~ns}$ \\
\hline
\end{tabular}

SEM: Pooled standard error of the mean.

\section{DISCUSSION}

Rabbit's growth rate wasn't influenced by the use of the carob and feed intake and FCR was not decreased by carob inclusion. In contrary, Abu Hafsa et al. (2016) reported that the increase in inclusion rate of carob pods from $0,2.5 ; 5$ to $10 \%$ significantly decreased feed intake, while they recorded, among diets containing the best value of feed conversion ratio in the diet containing $5 \%$ carob pods. However, several authors studying the effect of a low digestible fiber source incorporating ( $\mathrm{ADF}$ and $\mathrm{ADL}$ ) into growing rabbit's diets, founded a significant decrease in ADGg (Alvarez et al., 2007 and Nicodemus et al. (2002). Hence, it appears that the carob contains compounds that compensated the negative effect of lignocellulose on rabbit growth. Furthermore, our results revealed that carob diet reduced significantly mortality rate. This important finding is probably due to the positive effects of secondary components such as tannins. In fact, Kermauner and Laurenčič (2008) mentioned that tannins limit peristaltic activity in digestive disorders and can protect intestinal mucosa against oxidative damage and pathogens preventing diarrhea, the principal cause of mortality in rabbit. Moreover, carob with its antioxidant nutrients may attenuate substantially heat stress effects in growing rabbits in Tunisian summer conditions. Kamal et al. (2013) reported that carob powder is a rich source of soluble dietary fiber, minerals (Fe, Ca, Na, K, P and S) and vitamins (E, D, C, Niacin, B6 and folic acid). It contains in addition eleven phenolic compounds essentially Pyrogallol, catechol, chlorogenic and protocatechuic recorded the highest values. The same authors confirmed that carob powder is acclaimed ingredient with a marked nutritional value due to its high dietary fiber and phenol compounds. Sebai et al. (2013) demonstrated that Tunisian carob pods' extracts contained high contents of phenolic compounds. They reported also the aqueous extract showed antioxidant capacity and properties in rats by decreasing the tissues lipid peroxidation and hydrogen peroxide contents.

Our findings showed that carob decreased hot and commercial carcass $(\mathrm{p}<0.05)$, however both carcass yields were similar. Abu Hafsa et al. (2017) detected that $10 \%$ of feed inclusion of carob decreased the slaughter weight and carcass dressing percentage weight. Empty stomach and colon and liver proportions were higher in carob rabbits. According to Dalle-Zotte (2002) and Combes and Lebas (2003), feed inclusion of carob in growing rabbit diets has almost no effect on carcass composition, with the exception of a difference in the relative weights of the liver and 
hind part. The gastrointestinal tract proportion is comparable to that of Alvarez et al. (2007), but opposes the result of Nicodemus et al. (2002). Gruendel et al. (2007) founded that the ingestion of carob has the advantage of reducing the postprandial glucose level by storage in the liver, thus increasing the weight of this organ. Liu et al. (2009) reported that with the increase of tannins levels, the ratio (liver weight/live body weight) $\times 100$, decreased. However, Mohamed et al. (2001) suggested that higher levels of tannins might have a toxic effect. They reported an increase in the liver weight in rabbits fed high-tannin, but not in those fed low-tannin. Moreover, tannins' content in carob may enhance the lipid metabolism by promoting their use by oxidation (Gruendel et al., 2007), and contribute to the reduction of adiposity. Similarly, Kotrotsios et al. (2012) using carob in the pigs' diet did not show any effect on carcass adiposity. Carob feed affected empty stomach and colon weights, since their lignocellulose and lignin contents are different, and consequently retention time of feed particles in the different digestive tract segments would be variable. Moreover, studies on the influence of environmental parameters on the quality of the carcass and meat focus mainly on the effects of temperature. At temperatures high $\left(30{ }^{\circ} \mathrm{C}\right)$ or during summer, the decrease in feed intake and growth performance of animals, induce a carcass low weight but with a better yield due to the decrease of the relative weight of the skin and the tube digestive tract.

Carob feed did not affect the initial and ultimate $\mathrm{pH}$. Our results corroborate with those found by Marguenda et al. (2008) in meat of rabbits receiving a feed containing lower digestible fiber. These results are also, in agreement with those of Liu et al. (2009), who found that chestnut tannins didn't affect $\mathrm{pH} 24 \mathrm{~h}$ value. This was also confirmed by Hernandez and Dalle-Zotte (2010), who reported that feeding doesn't affect either the initial $\mathrm{pH}$ or the ultimate $\mathrm{pH}$. Dal Bosco et al. (2014) detected the same tendency for the $\mathrm{pH}$ evolution; it's significantly increased with time. Cabanes et al. (1996) reported that $\mathrm{pH}$ variations depend on two opposite events: the hydrolysis of proteins, with $\mathrm{NH}_{3}$ release, and the hydrolysis of lipids with release of fatty acid. Hernandez and Dalle Zotte (2010) and Liu et al. (2009) did not observe any diet effect on water holding capacity in rabbit meat. In contrast, Dal Bosco et al., (2014) detected a significant drip loss reduction in Thyme group. We noted that LD is characterized by a high lightness and redness indexes $\left(\mathrm{L}^{*}=70\right.$ and $\left.\mathrm{a}^{*}=8\right)$, respectively associated probably to myoglobin content. Hernandez and Dalle-Zotte (2010) reported lower, color indexes values in LD muscle (L*: 56 60, $\left.a^{*}: 2.06-3.04, b^{*}: 4-5\right)$. Color parameters $\left(L^{*}, a^{*}, b^{*}\right)$ of LD muscle were not affected by carob feed inclusion at $20 \%$. Our results corroborate with those of Liu et al. (2009). However, Dal Bosco et al., (2014) reported that the dietary spirulina and thyme supplementation had a significant effect on redness and yellowness evolution of LD muscle. Dal Bosco et al. (2012) reported that the chemical composition of longissimus lumborum muscle was not affected by the diet. In addition, our sensory evaluation results of color and juiciness demonstrated that carob didn't have any incidence on sensory quality of rabbit meat. Dalle-Zotte (2002) mentioned that the traditional consumer considered rabbit meat to have positive sensory properties: it is tender, lean and flavored.

\section{CONCLUSION}

It is concluded that carob feed inclusion at $20 \%$ in fattening rabbit diet, had no negative incidence on growth performance and improved significantly animal viability in summer conditions in Tunisia. Furthermore, carcass traits were not globally affected by the diets. Carob 
Vol. 4, No. 03; 2019

ISSN: $2456-8643$

diet seems to reduce adiposity in carcass and no differences were detected by the panelists in terms of the sensory meat quality. However, by incorporating this resource, we must put into consideration the nutritional requirements of rabbits, and especially to keep a balanced rate of fiber, especially ADF and ADL. Thus, carob pods are a local feed resource available in Tunisia that may represent a good alternative to imported raw materials, in helping to reduce the feed cost for Tunisian rabbit farmers.

\section{ACKNOWLEDGEMENTS}

The authors would like to express their acknowledgements to the Spanish agency of the international cooperation and the Tunisian Institution of Agricultural Research and Higher Education -Ministry of Agriculture, for funding this study.

\section{REFERENCES}

Norme AFNOR NF-47-001 - Available on Internet at the URL http://www.cuniculture.info/Docs/Phototheque/Abattage/Carcasse-Decoupe/Notes-de-gras-

Lapin.pdf

Abu Hafsa S. H., Ibrahim S. A. and Hassan A. A., 2017. Carob pods (Ceratonia siliqua L.) improve growth performance, antioxidant status and caecal characteristics in growing rabbits. Journal of animal physiology and animal nutrition, 101:6.

Alvarez J.L., Marguenda I., García-Rebollar P., Carabaño R., De Blas C., Corujo A., GarcíaRuiz A.I., 2007. Effects of type and level of fiber on digestive physiology and performance in reproducing and growing rabbits. World Rabbit Sci., 15: 9-17.

AOAC., 1995. Official methods of analysis of Association of Official Analytical Chemists, $16^{\text {th }}$ edition. AOAC, Washington, DC.

Blasco A., Ouhayoun J., 1996. Harmonization of criteria and terminology in rabbit meat research. Revised proposal. World Rabbit Sci., 4: 93- 9. https://doi.org/10.4995/wrs.1996.278

Combes S. and Lebas F., 2003. Les modes de logement du lapin en engraissement :

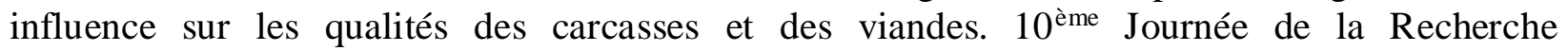
Cunicole. Paris. 19-20.

Dal Bosco A., Mourvaki E., Cardinali R., Servili M., Sebastiani B., Ruggeri S., Mattioli S., Taticchi A., Esposto S., Castellini C., 2012. Effect of dietary supplementation with olive pomaces on the performance and meat quality of growing rabbits. Meat Sci., 92: 783-788. https://doi: 10.1016/j.meatsci.2012.07.001.

Dal Bosco A., Gerencsér Zs., Szendrő Zs., Mugnai C., Cullere M., Kovàcs M., Ruggeri S., Mattioli S., Castellini C., Dalle Zotte A., 2014. Effect of dietary supplementation of Spirulina (Arthrospira platensis) and Thyme (Thymus vulgaris) on rabbit meat appearance, oxidative stability and fatty acid profile during retail display. Meat Sci., 96: 114-119. Https:// doi: 10.1016/j.meatsci.2013.06.021

De Blas J. C., Mateos G. G., Rebollar P. G., 2003. Tablas FEDNA de composición y valor nutritivo de alimentos para la fabricación de piensos compuestos. Fundación Española para el Desarrollo de la Nutrición Animal. Spain.

FAOSTAT, 2018. http://www.fao.org/faostat/en/\#home GIPAC, 2018. Groupement interprofessionnel des produits avicoles et cunicoles. Tunisia. 
Gruendel S., Otto B., Garcia A. L., Wagner K., Mueller C., Weickert M. O., Heldwein W., Koebnick C., 2007. Increased acylated plasma ghrelin, but improved lipid profiles 24-h after intake of carob pulp preparation rich in dietary fibre and polyphenols. Br J Nutr.. 98: 1170 1177. http://doi : $10.1017 /$ S0007114507777127

Hernandez P., Dalle Zotte A., 2010. Influence of diet on rabbit meat quality. De Blas C. et Wiseman J. Nutrition of the rabbit. CAB International Edition. 9: 163-178.

Honikel K. O. 1998. Reference methods for the assessment of physical characteristics of meat. Meat Sci., 49: 447-457.

R.Julkunen-Titto. (1985). Phenolic constituents in the leaves of northem wiliows methods forthe analysis of certain phenolics. Journal of Agricultural and Food chemistry, Vol. 33(2), page : 213. DOI: $10.1021 /$ jf00062a013.

Kamal M. Youssef E., Moshera M. El-Manfaloty and Hend Ali M. 2013. Assessment of Proximate Chemical Composition, Nutritional Status, Fatty Acid Composition and Phenolic Compounds of Carob (Ceratonia Siliqua L.) Food and Public Health, 3(6): 304-308 DOI: 10.5923/j.fph.20130306.06

Kermauner A., Laurenčič A., 2008. Supplementation of rabbit diet with chestnut wood extract: Effect on in vitro gas production from two sources of protein. In Proceedings of the $9^{\text {th }}$ world rabbit congress. 10-13 June 2008, Verona, Italy. 689-693.

Kotrotsios N., Christaki E., Bonos E., Florou-Paneri P., 2012. Dietary carob pods on growth performance and meat quality of fattening pigs. Asian- Australasian J Anim Sci., 25 : 880 -885. http://doi: 10.5713/ajas.2011.11521

OEP. 2018. Rapport de la commission de la production animale. Office de l'élevage et des pâturages. Ministère de l'agriculture de l'agriculture des ressources hydriques et de la pêche, Tunisia.

Liu H.W., Gai F., Gasco L., Brugiapaglia A., Lussiana C. Guo K.J., Tong J.W., Zoccarato I., 2009. Effects of chestnut tannins on carcass characteristics, meat quality, lipid oxidation and fatty acid composition of rabbits. Meat Sci., 83: 678-683. http://dx.doi.org/10.5424/sjar/2016142-8728.

MAKKAR H.P.S. and BECKER K. Vanillin-HCL method for condensed tannins: Effect of organic solvents used for extraction of tannins. Journal of Chemical Ecology, Vol. 19, No. 4, Mohamed A. M., Molham A. H., Abdulwali A. A., Abdulkarim A. O., 2001. In vivo effects of dietary sorghum tannins on rabbit digestive enzymes and mineral absorption. Nutrition Research., 21 : 1393-1401. https://doi.org/10.1016/S0271-5317(01)00334-7.Nicodemus N., García J., Carabaño R., De Blas J. C., 2002. Effect of inclusion of sunflower hulls in the diet on performance, disaccharidase activity in the small intestine and caecal traits of growing rabbits. Animal Science., 75: 237- 243. https://doi.org/10.1017/S1357729800052991

ebai H, Souli A., Chehimi L., Rtibi K., Amri M., El-Benna J. and Sakly M., 2013. In vitro and in vivo antioxidant properties of Tunisian carob (Ceratonia siliqua L.). Journal of Medicinal Plants Research Vol. 7(2), pp. 85-90, 10 January, http://www.academicjournals.org/JMPR DOI: 10.5897/JMPR12.915 ISSN 1996-0875. Van Soest P. J., Robertson J. B., Lewis B. A., 1991. Methods for dietary fiber, neutral detergent fibre and non-starch polysaccharides in relation to animal nutrition. Journal of Dairy Science, 74: 3583-3597. https://doi :10.3168/jds.S0022$\underline{0302(91) 78551-2}$ 